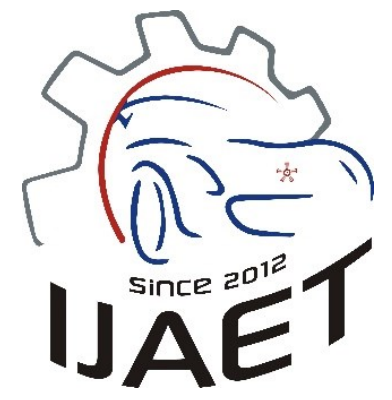

e-ISSN: $2146-9067$

International Journal of Automotive

Engineering and Technologies

journal homepage:

https://dergipark.org.tr/en/pub/ijaet

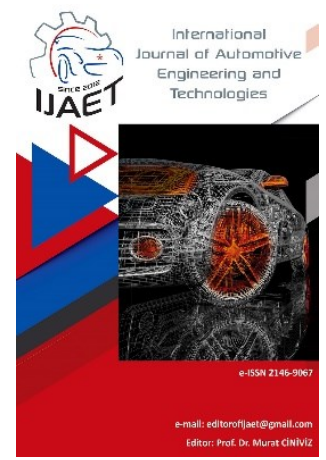

Original Research Article

\title{
Influence of $\mathrm{NiFe}_{2} \mathrm{O}_{4}$ and $\mathrm{Zn}_{0.5} \mathrm{Ni}_{0.5} \mathrm{Fe}_{2} \mathrm{O}_{4}$ nanoparticles on exhaust emissions of 4 stroke-6 cylinders turbocharged diesel engine
}

\author{
Ceyla Özgür ${ }^{{ }^{*}}$
}

1* Adana Alparslan Türkeş Science and Technology University, Engineering Faculty, Energy Systems Engineering Department, Adana, Turkey

ARTICLE INFO
1. 0000-0002-4072-6784
Doi: 10.18245/ ijaet.781493
* Corresponding author
cozgur@atu.edu.tr
Received: Agu 18, 2020
Accepted: Feb 21, 2021
Published: Mar 31, 2021
Published by Editorial Board
Members of IJAET
C) This article is distributed by
Turk Journal Park System under
the CC 4.0 terms and conditions.

\section{Introduction}

Petroleum resources have a huge role in energy demanding. However, the depletion of petroleum fuels is increasing rapidly [1]. In the world diesel engines are mostly used in motor vehicles, automobiles, manufacturing power generation, farming [2-3]. Diesel vehicles induced to the many air pollutants like carbon monoxide, carbon dioxide, hydrocarbons, particulate matter, nitrogen oxides and soot emissions [4-5]. Due to the economic and environmental concerns have led to the find alternative fuel for diesel engine [6]. Various fuel additives are used in order to beat adverse effects of diesel fuel [7-8]. According to many research studies that adding nanoparticle to diesel and biodiesel fuels improve combustion efficiency and reduction exhaust emissions [911]. Many researchers used metal-based additives which posses' desirable properties such as high thermal conductivity, surfacevolume ratio, and better ignition characteristics [12]. There are many nano additives such as zinc oxide, manganese, carbon nanotube, cerium oxide, iron oxide, alumina, copper oxide, titanium oxide, magnesium oxide $[3,7,13]$.

Rastogi et. al [12] carried out experimentally study to find the effects of $\mathrm{CuO}$ nanoparticles on performance of diesel engine, emission and combustion characteristics which runs on jojoba 
biodiesel blend (JB20) as a fuel. They added 25, 50 and $75 \mathrm{ppm} \mathrm{CuO}$ to JB20. They observed that BTE for the JB20CN50 fuel was higher than that of other Jojoba biodiesel fuel samples and engine emission hydrocarbons, $\mathrm{CO}$ and smoke emissions were also found lesser when the $\mathrm{CuO}$ nanoparticles added to JB20.

Srinidhi et. al [13] investigated the impacts of $\mathrm{NiO}$ nanoparticle doped azadirachta indica biodiesel-diesel fuel (NBE25) blend on CI engine performance at different fuel injection timing. Nickel oxide nanoparticle concentration was 25, 50, 75 and $100 \mathrm{ppm}$ in NBE25 base fuel. According to the outcomes there is an important reduction on $\mathrm{HC}$ and $\mathrm{CO}$ emissions for the nickel oxide mixed biodiesel compared with a biodiesel blend (NBE25).

Özgür et. al. [14] had examined the engine performance and emission parameters of diesel engine by using $\mathrm{SiO}_{2}$ and $\mathrm{MgO}$ nanoparticles mixed with rapeseed biodiesel. Nano particles were added to biodiesel with mass fractions of 25 and $50 \mathrm{ppm}$. According to the results, they observed a reduction in $\mathrm{NO}_{\mathrm{x}}$ and $\mathrm{CO}$ emission values and engine performance increased with the addition of $\mathrm{SiO}_{2}$ and $\mathrm{MgO}$ nanoparticle additives.

Mehregan and Moghiman [15] explored the effects of nano additives on performance and emission characteristics of diesel engine equipped with urea-SCR system fuelled with blended biodiesel fuel. They used manganese oxide and cobalt oxide as nanoparticle additives at the dosage of 25 and $50 \mathrm{ppm}$. They found that the brake specific fuel consumption and the brake thermal efficiency increased with the addition of nanoparticles and they observed reduction in the $\mathrm{NO}_{\mathrm{x}}$ and $\mathrm{CO}$ emissions compared to those of base fuel.

Kumar et. al. [16] studied the emission behaviour of four stroke, single cylinder, diesel engine fuelled diesel fuel adding with $\mathrm{TiO}_{2}$ nanoparticle. They added 50 and $100 \mathrm{ppm} \mathrm{TiO}_{2}$ nanoparticle to diesel fuel. They observed that adding 50 and $100 \mathrm{ppm}$ of $\mathrm{TiO}_{2}$ nanoparticles to diesel, significant reduction in $\mathrm{CO}, \mathrm{HC}, \mathrm{NO}_{\mathrm{x}}$, and smoke emissions.

The goal of this experimental work is to examine the influence of Nickel Iron Oxide and Nickel Zinc Iron oxide in diesel fuel as an additive to determine the exhaust emissions in 4 Stroke- 6 cylinder turbocharged diesel engine.

\section{Experimental Set up}

In this experimental study, diesel was used as fuel. Nickel iron oxide and nickel zinc iron oxide nanoparticle additives which are commercially available with size 30 nanometers were used to prepare fuel blends. The amount of nanoparticles that are required for all level of doses were measured using electronic precision scales with sensitivity of $0,0001 \mathrm{~g}$. The chosen dosage levels of nanoparticles were 15, 20 and $25 \mathrm{ppm}$. Nickel iron oxide and nickel zinc iron oxide nanoparticles added to diesel fuel with Sonic Vibra-Cell VC 750 model ultrasonic processer during half an hour to obtain a homogeneous fuel mixture. These test fuels were used in order to prevent any precipitation without delay. The properties of nanoparticles are given Table 1 .

Table 1. The Properties of nanoparticles

\begin{tabular}{cccc}
\hline Nanoparticle & Symbol & $\begin{array}{c}\text { Particle } \\
\text { Size } \\
\text { (nm) }\end{array}$ & $\begin{array}{c}\text { Purity } \\
\text { (\%) }\end{array}$ \\
\hline $\begin{array}{c}\text { Nickel Iron } \\
\text { Oxide }\end{array}$ & $\mathrm{NiFe}_{2} \mathrm{O}_{4}$ & 30 & 99.9 \\
$\begin{array}{c}\text { Nickel Zinc } \\
\text { Iron Oxide }\end{array}$ & $\mathrm{Zn}_{0.5} \mathrm{Ni}_{0.5} \mathrm{Fe}_{2} \mathrm{O}_{4}$ & 30 & 99.5 \\
\hline
\end{tabular}

The measured fuel properties are density, kinematic viscosity, cetane number and pour point. Table 2 represents the specifications of fuel properties measurement devices.

Table 2. Specifications of fuel devices

\begin{tabular}{ccc}
\hline Property & Device & Accuracy \\
\hline & Kyoto \\
Density $\left(\mathrm{kg} / \mathrm{m}^{3}\right)$ & Electronics DA- & $\pm 0.001 \mathrm{~g} / \mathrm{cm}^{3}$ \\
& 130 \\
Kinematic & Tanaka AKV- & $\pm 0.01 \mathrm{cSt}$ \\
viscosity $(\mathrm{cSt})$ & 202 & \pm 0.5 \\
Cetane number & Zeltex ZX 440 & $\pm 1^{\circ} \mathrm{C}$ \\
Pour Point $\left({ }^{\circ} \mathrm{C}\right)$ & Tanaka MPC & $102 \mathrm{~L}$ \\
\hline
\end{tabular}

In this work, a 6-cylinder, 4 stroke, turbocharged and charge air cooled intercooled diesel engine which was run on a hydraulic dynamometer is used. The technical properties of engine test show on Table 3. Lay out of the system was demonstrated in Figure 1. The experimental tests were conducted at full load condition between 1400 and $2200 \mathrm{rpm}$, with an interval of $200 \mathrm{rpm}$. AVL SESAM Fourier Transform Infrared Spectroscopy (FTIR) multicomponent exhaust analyser were used to measure exhaust emission concentrations. The 
accuracy of the measurements is 0.01 for all types of exhaust emissions.

In the after treatment process, selective catalytic reduction, which involves the spraying of urea in the tail pipe, was incorporated to mitigate $\mathrm{NO}_{\mathrm{x}}$. The engine is equipped with SCR aftertreatment system. The specifications of catalyst used in SCR system are shown in Table 4.

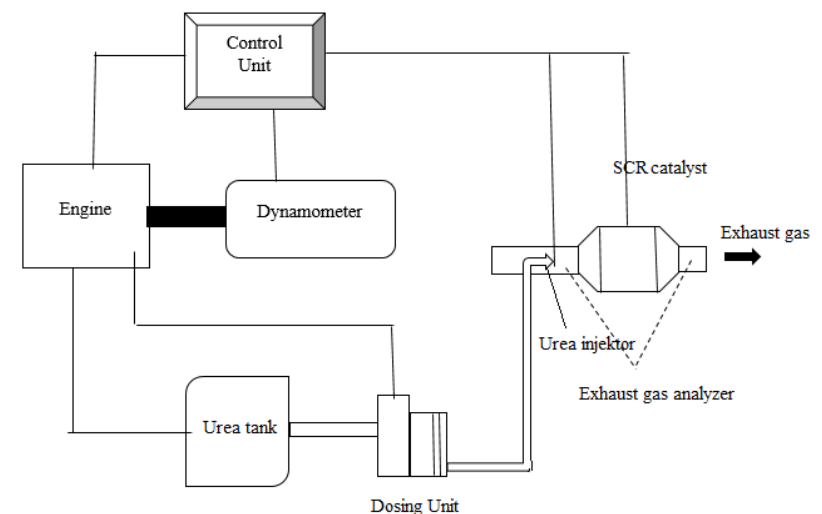

Figure 1. Lay out of the system

Table 3. Characteristics of test engine

\begin{tabular}{ll}
\hline \multicolumn{1}{c}{ Specifications } & \multicolumn{1}{c}{ Descriptions } \\
\hline Manufacturer/series type & Cummins ISBE4+250B \\
& Electronic control system, \\
Engine type & 4 stroke, 6 cylinder, \\
& Turbocharger \\
aftercooled & $107 \mathrm{~mm}$ \\
Bore & $124 \mathrm{~mm}$ \\
Ctroke & 17.3 \\
Displacement & $6700 \mathrm{cc}$ \\
Power & $184 \mathrm{~kW} @ 2500 \mathrm{rpm}$ \\
\hline
\end{tabular}

Table 4. Specifications of the catalyst in Aftertreatment system

\begin{tabular}{ll}
\hline \multicolumn{1}{c}{ Specifications } & \multicolumn{1}{c}{ Descriptions } \\
\hline Diameter $(\mathrm{m})$ & 0.2667 \\
Length (m) & 0.3048 \\
Cell Geometry & Honeycomb type square \\
celled catalyst & 17 \\
Total Volume (L) & 400 \\
Cell Density/in ${ }^{2}$ & 1.2 \\
Cell Width (mm) & 1.86 \\
Open Frontal Area (m) & 0.105 \\
Wall Thickness (mm) conductivity & 0.4 \\
Thermal col & \\
(W/m.K) &
\end{tabular}

\section{Results and Discussion}

\subsection{Fuel properties}

Density, viscosity, cetane number and pour point values were measured according to the standards. The fuel properties of diesel fuel and test fuels are demonstrated in Table 5 .
According to the table, density and pour point of diesel fuel does not show important variation, with the addition of nanoparticles to diesel fuel. The viscosity of diesel fuel was slightly increased with the addition of nanoparticles to diesel fuel. Cetane number of the test fuels decreased with the addition of nanoparticles. Cetane number is the the ignition quality of a fuel. Decrease in the cetane number means decrease in the ignition quality of the fuel which will lead to poor combustion of the fuel in the combustion chamber [17].

Table 5. Fuel properties of diesel fuel and test fuels

\begin{tabular}{|c|c|c|c|c|}
\hline Property & Density & Viscosity & $\begin{array}{l}\text { Cetane } \\
\text { number }\end{array}$ & $\begin{array}{l}\text { Pour } \\
\text { Point }\end{array}$ \\
\hline Units & $\mathrm{kg} / \mathrm{m}^{3}$ & $\overline{\mathrm{cSt}}$ & - & ${ }^{\circ} \mathrm{C}$ \\
\hline Diesel & 840 & 3.5 & 59 & -13 \\
\hline $\begin{array}{l}15 \text { ppm Ni } \\
\mathrm{Fe}_{2} \mathrm{O}_{4}\end{array}$ & 840 & 3.6 & 50 & -13 \\
\hline $\begin{array}{l}20 \text { ppm Ni } \\
\mathrm{Fe}_{2} \mathrm{O}_{4}\end{array}$ & 840 & 3.6 & 51 & -13 \\
\hline $\begin{array}{l}25 \text { ppm } \mathrm{Ni} \\
\mathrm{Fe}_{2} \mathrm{O}_{4}\end{array}$ & 841 & 3.7 & 53 & -13 \\
\hline $\begin{array}{lr}15 & \mathrm{ppm} \\
\mathrm{Zn}_{0.5} \mathrm{Ni}_{0.5} \mathrm{Fe}_{2} \mathrm{O}_{4}\end{array}$ & 841 & 3.7 & 49 & -13 \\
\hline $\begin{array}{lr}20 & \mathrm{ppm} \\
\mathrm{Zn}_{0.5} \mathrm{Ni}_{0.5} \mathrm{Fe}_{2} \mathrm{O}_{4}\end{array}$ & 841 & 3.8 & 51 & -13 \\
\hline $\begin{array}{lr}25 & \mathrm{ppm} \\
\mathrm{Zn}_{0.5} \mathrm{Ni}_{0.5} \mathrm{Fe}_{2} \mathrm{O}_{4}\end{array}$ & 842 & 3.9 & 52 & -13 \\
\hline
\end{tabular}

\section{2. $\mathrm{NO}_{\mathrm{x}}$ Emissions}

Figure 2 is given $\mathrm{NO}_{\mathrm{x}}$ emissions of test fuels versus engine speed. The chosen addition dosage of $\mathrm{NiFe}_{2} \mathrm{O}_{4}$ nanoparticle is 15,20 and 25 ppm. As the nanoparticle dosage increased, a reduction in the emission values was observed. The percentage alteration of $\mathrm{NO}_{\mathrm{x}}$ emissions of test fuels compared to neat diesel fuel is given in Figure 3. According to the results, the average reduction is $5.5 \%, 7.4 \%$ and $8.5 \%$ for the addition dosage of 15,20 and $25 \mathrm{ppm}$ respectively.

The variations of $\mathrm{NO}_{\mathrm{x}}$ emission values of $\mathrm{Zn}_{0.5} \mathrm{Ni}_{0.5} \mathrm{Fe}_{2} \mathrm{O}_{4}$-diesel fuel blends with different engine speed is demonstrated in Figure 4. According to the results the maximum reduction in $\mathrm{NO}_{\mathrm{x}}$ emissions was measured with modified fuel with the $\mathrm{Zn}_{0.5} \mathrm{Ni}_{0.5} \mathrm{Fe}_{2} \mathrm{O}_{4}$ addition dosage of $25 \mathrm{ppm}$. The maximum nitrogen oxides emission decrease was acquired at $2200 \mathrm{rpm}$ engine speeds for the all test fuels. The average reduction in $\mathrm{NO}_{\mathrm{x}}$ emission is $2.3 \%, 3.2 \%$ and $4.7 \%$ with respect to neat diesel at the addition 
Table 6. The changes in $\mathrm{NO}_{\mathrm{x}}$ emissions with the addition of nanoparticles to diesel engine

\begin{tabular}{|c|c|c|c|c|}
\hline \multicolumn{5}{|c|}{$\mathrm{NiFe}_{2} \mathrm{O}_{4}$-diesel fuel blends } \\
\hline $\mathrm{rpm}$ & Diesel & $15 \mathrm{ppm} \mathrm{NiFe}_{2} \mathrm{O}_{4}$ & 20 ppm $\mathrm{NiFe}_{2} \mathrm{O}_{4}$ & $25 \mathrm{ppm} \mathrm{NiFe}_{2} \mathrm{O}_{4}$ \\
\hline 1400 & 1128.0000 & 1041.0000 & 1035.0000 & 1023.0000 \\
\hline 1600 & 998.0000 & 978.0000 & 970.0000 & 962.0000 \\
\hline 1800 & 939.0000 & 918.0000 & 872.0000 & 863.0000 \\
\hline 2000 & 865.0000 & 830.0000 & 805.0000 & 800.0000 \\
\hline 2200 & 828.0000 & 732.0000 & 728.0000 & 712.0000 \\
\hline \multicolumn{5}{|c|}{$\mathrm{Zn}_{0.5} \mathrm{Ni}_{0.5} \mathrm{Fe}_{2} \mathrm{O}_{4}$-diesel fuel blends } \\
\hline $\mathrm{rpm}$ & Diesel & $15 \mathrm{ppm} \mathrm{Zn}_{0.5} \mathrm{Ni}_{0.5} \mathrm{Fe}_{2} \mathrm{O}_{4}$ & 20 ppm $\mathrm{Zn}_{0.5} \mathrm{Ni}_{0.5} \mathrm{Fe}_{2} \mathrm{O}_{4}$ & $25 \mathrm{ppm} \mathrm{Zn}_{0.5} \mathrm{Ni}_{0.5} \mathrm{Fe}_{2} \mathrm{O}_{4}$ \\
\hline 1400 & 1128.0000 & 1107 & 1102 & 1098 \\
\hline 1600 & 998.0000 & 971 & 967 & 960 \\
\hline 1800 & 939.0000 & 937 & 932 & 910 \\
\hline 2000 & 865.0000 & 861 & 852 & 840 \\
\hline 2200 & 828.0000 & 775 & 758 & 735 \\
\hline
\end{tabular}

dosage of 15, 20 and $25 \mathrm{ppm}$ respectively. The reason of the reductions in NOx emission of diesel fuels with the addition nanoparticles is complete combustion of oxygenated fuel blends with the help of catalyst effect of nanoparticle additions which promotes heat transfer in the combustion chamber due to their metallic-base structures [18].

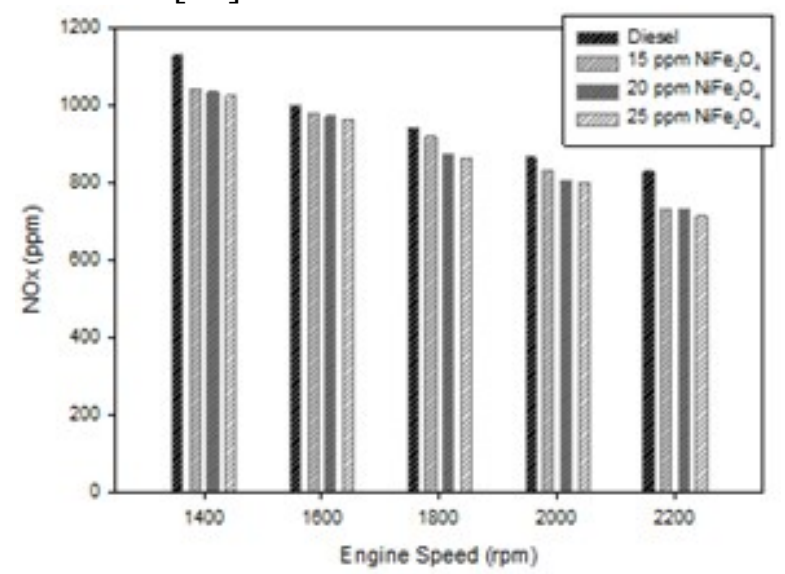

Figure 2. Experimental $\mathrm{NO}_{\mathrm{x}}$ emission data to $\mathrm{NiFe}_{2} \mathrm{O}_{4}$ diesel

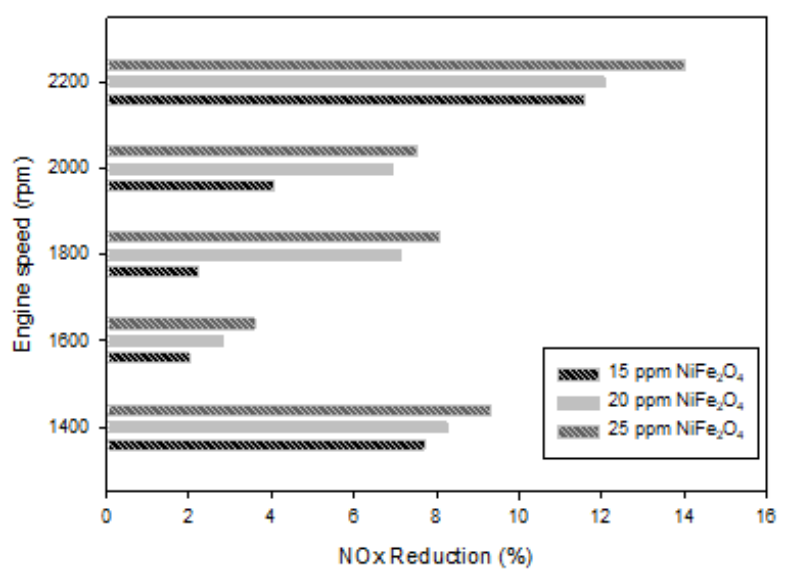

Figure 3. Percentage alteration of $\mathrm{NO}_{\mathrm{x}}$ emissions of test fuels compared to diesel fuel

Table 6 gives the changes in $\mathrm{NO}_{\mathrm{x}}$ emissions with the addition of nanoparticle to diesel fuel at different engine speeds.

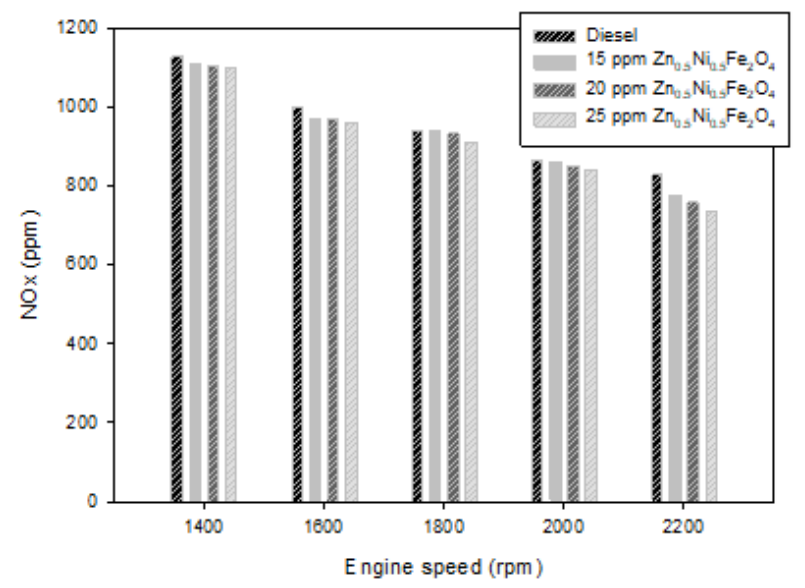

Figure 4. Impacts of $\mathrm{Zn}_{0.5} \mathrm{Ni}_{0.5} \mathrm{Fe}_{2} \mathrm{O}_{4}$-diesel blends on NOx Emission

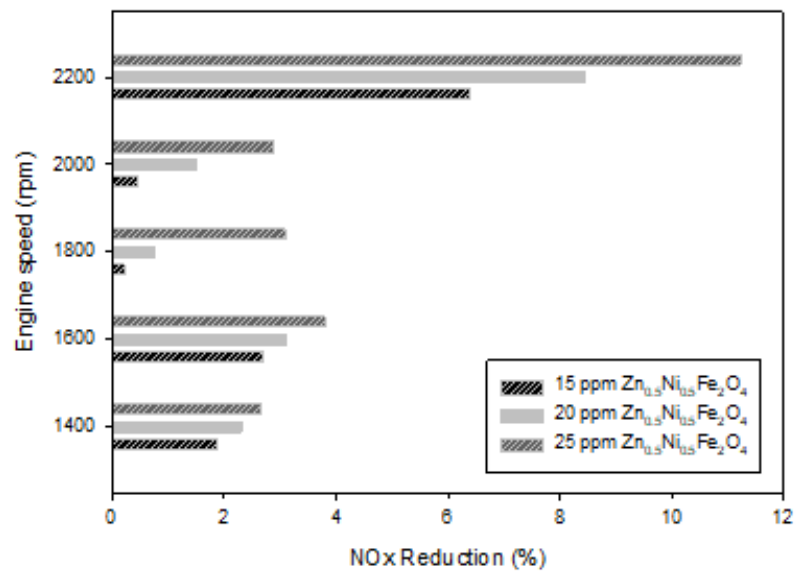

Figure 5. Percentage alteration of $\mathrm{NO}_{\mathrm{x}}$ emissions of test fuels compared to diesel fuel

\subsection{CO Emissions}

Figure 6 presents the carbon monoxide $(\mathrm{CO})$ emissions of modified fuel blends. It is observed that $\mathrm{CO}$ emissions are decreased with the addition of $\mathrm{NiFe}_{2} \mathrm{O}_{4}$ nanoparticle to diesel fuel. Figure 7 shows percentage alteration of $\mathrm{CO}$ emissions of test fuels compared to neat diesel fuel. The average reduction in $\mathrm{CO}$ emission with 
Table 7. The changes in $\mathrm{CO}$ emissions with the addition of nanoparticles to diesel engine

\begin{tabular}{|c|c|c|c|c|}
\hline \multicolumn{5}{|c|}{$\mathrm{NiFe}_{2} \mathrm{O}_{4}$-diesel fuel blends } \\
\hline $\mathrm{rpm}$ & Diesel & $15 \mathrm{ppm} \mathrm{NiFe}_{2} \mathrm{O}_{4}$ & $20 \mathrm{ppm} \mathrm{NiFe}_{2} \mathrm{O}_{4}$ & $25 \mathrm{ppm} \mathrm{NiFe}_{2} \mathrm{O}_{4}$ \\
\hline 1400 & 88 & 85.0000 & 82.0000 & 79.0000 \\
\hline 1600 & 77 & 74.0000 & 71.3000 & 70.0000 \\
\hline 1800 & 125 & 118.0000 & 110.0000 & 105.8000 \\
\hline 2000 & 402 & 395.0000 & 382.0000 & 378.2000 \\
\hline 2200 & 439 & 418.0000 & 411.0000 & 407.8000 \\
\hline \multicolumn{5}{|c|}{$\mathrm{Zn}_{0.5} \mathrm{Ni}_{0.5} \mathrm{Fe}_{2} \mathrm{O}_{4}$-diesel fuel blends } \\
\hline rpm & Diesel & $15 \mathrm{ppm} \mathrm{Zn}_{0.5} \mathrm{Ni}_{0.5} \mathrm{Fe}_{2} \mathrm{O}_{4}$ & $20 \mathrm{ppm} \mathrm{Zn}_{0.5} \mathrm{Ni}_{0.5} \mathrm{Fe}_{2} \mathrm{O}_{4}$ & $25 \mathrm{ppm} \mathrm{Zn}_{0.5} \mathrm{Ni}_{0.5} \mathrm{Fe}_{2} \mathrm{O}_{4}$ \\
\hline 1400 & 88 & 86 & 83 & 78 \\
\hline 1600 & 77 & 76 & 75 & 73 \\
\hline 1800 & 125 & 111 & 108 & 105 \\
\hline 2000 & 402 & 399 & 395 & 386 \\
\hline 2200 & 439 & 435 & 431 & 428 \\
\hline
\end{tabular}

respect to neat diesel result $3.9 \%, 7.5 \%$ and $9.5 \%$ with respect to diesel at the $\mathrm{NiFe}_{2} \mathrm{O}_{4}$ nanoparticle addition dosage of 15, 20 and 25 ppm respectively.

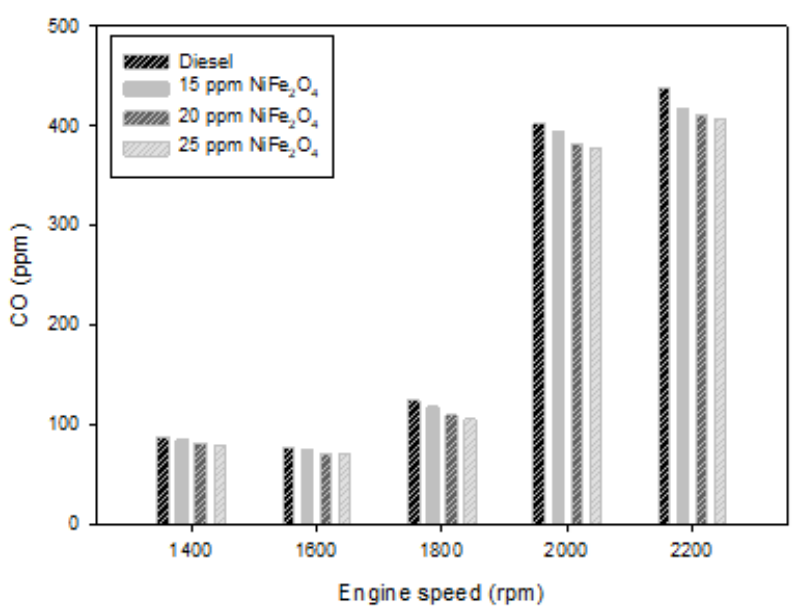

Figure 6. $\mathrm{CO}$ emissions of $\mathrm{NiFe}_{2} \mathrm{O}_{4}$-diesel blends at different engine speeds

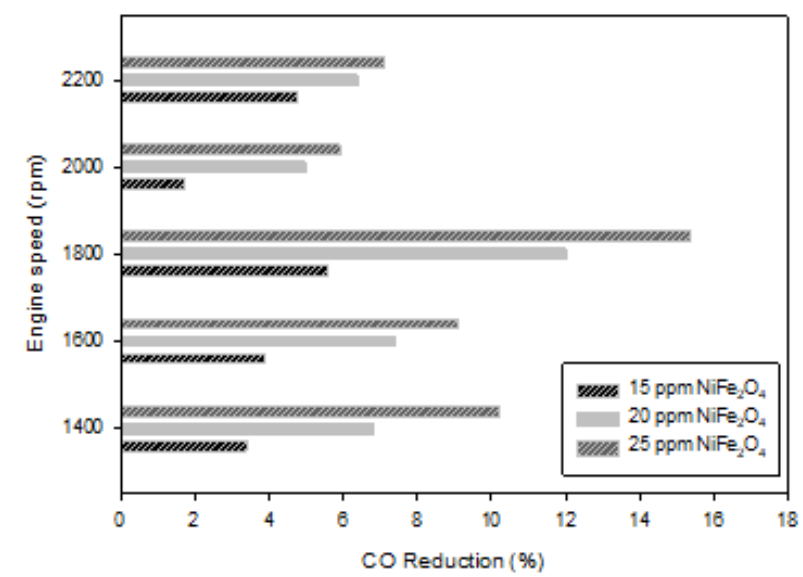

Figure 7. Percentage alteration of $\mathrm{CO}$ emissions of test fuels compared to diesel fuel

Figure 8 shows the carbon monoxide $(\mathrm{CO})$ emissions of $\mathrm{Zn}_{0.5} \mathrm{Ni}_{0.5} \mathrm{Fe}_{2} \mathrm{O}_{4}$-diesel fuel blends at different engine speeds. According to the results nanoparticle addition dosage of 15,20 and $25 \mathrm{ppm}$ decreased the $\mathrm{CO}$ emissions with

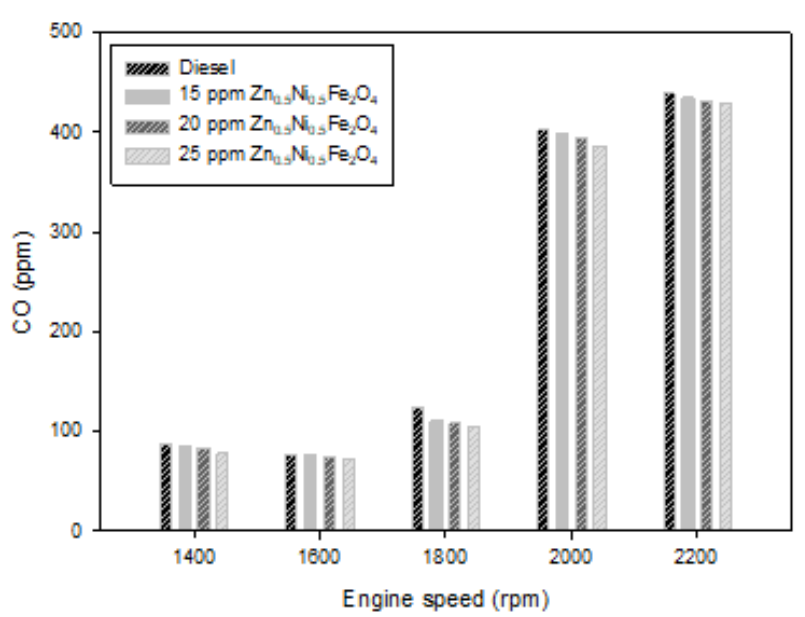

Figure 8. CO emissions of $\mathrm{Zn}_{0.5} \mathrm{Ni}_{0.5} \mathrm{Fe}_{2} \mathrm{O}_{4}$-diesel blends at different engine speeds

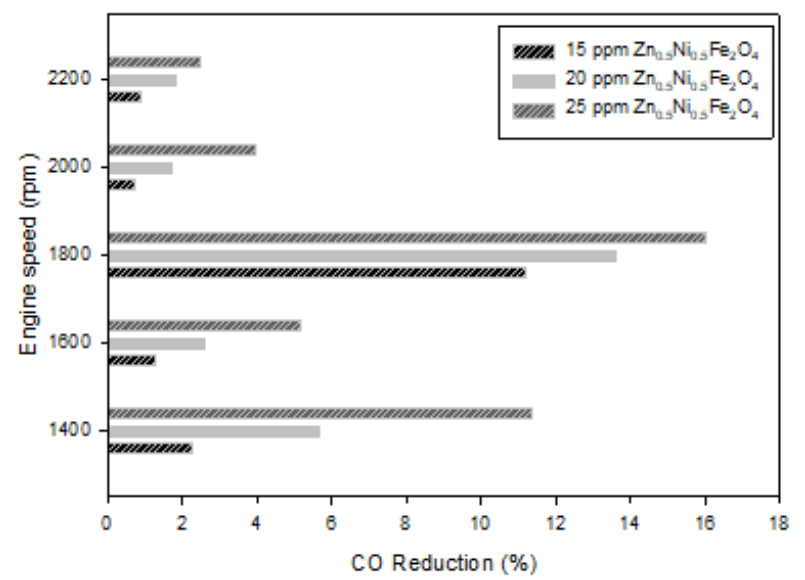

Figure 9. Percentage alteration of $\mathrm{CO}$ emissions of test fuels compared to diesel fuel

respect to diesel fuel. The maximum $\mathrm{CO}$ emission reduction was get at between 1400 and $1800 \mathrm{rpm}$ engine speed. The average reduction is $3.3 \%, 5.1 \%$ and $7.8 \%$ with respect to diesel at the addition dosage of 15,20 and $25 \mathrm{ppm}$ respectively. The reason for the carbon monoxide emission is incomplete combustion, which is raised by a lack of oxidants, residence time, and temperature. The $\mathrm{CO}$ emissions 
decrease slightly with the use of nanoparticle additives. This may be owing to the catalytic activity of nanoparticles and improving the fuel-air mixing in the combustion chamber, and in turn resulting in reduced CO emissions [19]. Table 7 shows the changes in $\mathrm{CO}$ emissions with the addition of nanoparticle to diesel fuel at different engine speeds.

\subsection{HC Emissions}

The hydrocarbon (HC) emissions of modified test fuels is given in Figure 10. $\mathrm{NiFe}_{2} \mathrm{O}_{4}$ nanoparticle additive amount of 15, 20 and 25 ppm decreased the $\mathrm{HC}$ emissions values of the diesel fuel. Figure 11 gives percentage alteration of $\mathrm{HC}$ emissions of test fuels compared to neat diesel fuel. The average reduction in $\mathrm{HC}$ emissions is $3.3 \%, 4.4 \%$ and $5.2 \%$ with respect to neat diesel at the $\mathrm{NiFe}_{2} \mathrm{O}_{4}$ nanoparticle addition dosage of 15,20 and $25 \mathrm{ppm}$ respectively.

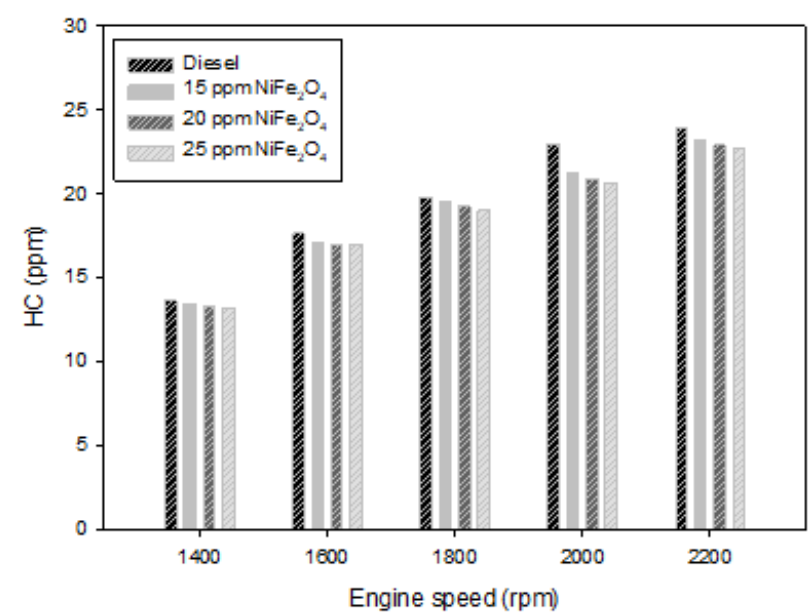

Figure 10. Impacts of $\mathrm{NiFe}_{2} \mathrm{O}_{4}$-diesel blends on $\mathrm{HC}$ Emission

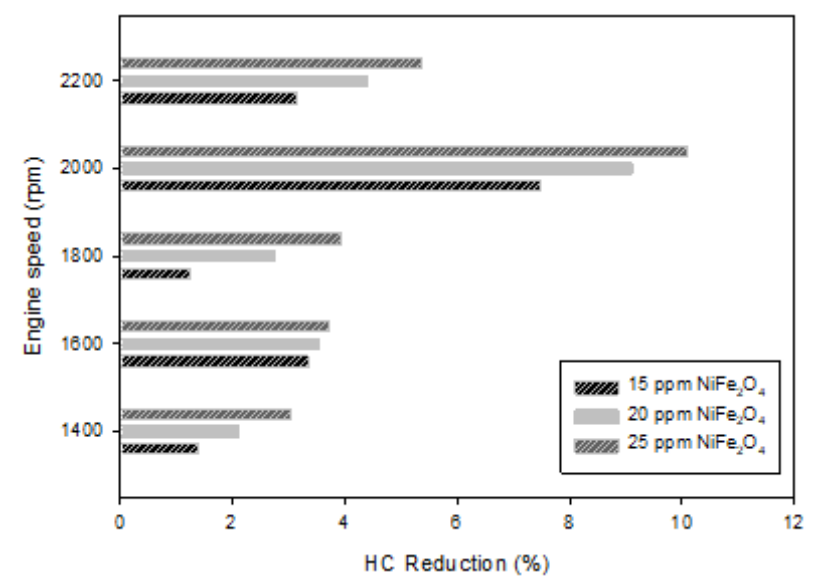

Figure 11. Percentage alteration of HC emissions of test fuels compared to diesel fuel

Hydrocarbon emission values of test fuels at different engine speeds are given in Figure 12.
$\mathrm{Zn}_{0.5} \mathrm{Ni}_{0.5} \mathrm{Fe}_{2} \mathrm{O}_{4}$ nanoparticle additive decreased the $\mathrm{HC}$ emissions values of the diesel fuel. The average reduction is $2.8 \%, 3.6 \%$ and $5.4 \%$ according to neat diesel at the $\mathrm{Zn}_{0.5} \mathrm{Ni}_{0.5} \mathrm{Fe}_{2} \mathrm{O}_{4}$ nanoparticle addition dosage of 15, 20 and 25 ppm respectively. The average reduction in $\mathrm{HC}$ emission values decreased with the increased dosage of $\mathrm{Zn}_{0.5} \mathrm{Ni}_{0.5} \mathrm{Fe}_{2} \mathrm{O}_{4}$ nanoparticle addition to diesel fuel. $\mathrm{HC}$ emissions contribute to the formation of smog and may include photo chemically reactive species as well as carcinogens. Nano additive addition has been shown to decrease $\mathrm{HC}$ emissions. Reduction in $\mathrm{HC}$ emissions may be due to secondary atomization, shorten ignition delay, and catalytic activity of nano additives leading to better combustion [20].

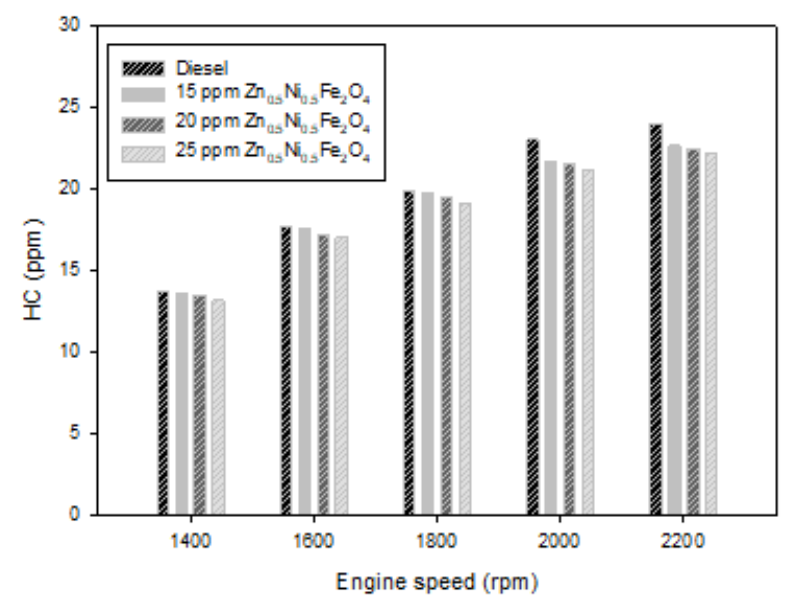

Figure 12. Effect of $\mathrm{Zn}_{0.5} \mathrm{Ni}_{0.5} \mathrm{Fe}_{2} \mathrm{O}_{4}$-diesel blends on $\mathrm{HC}$ emission

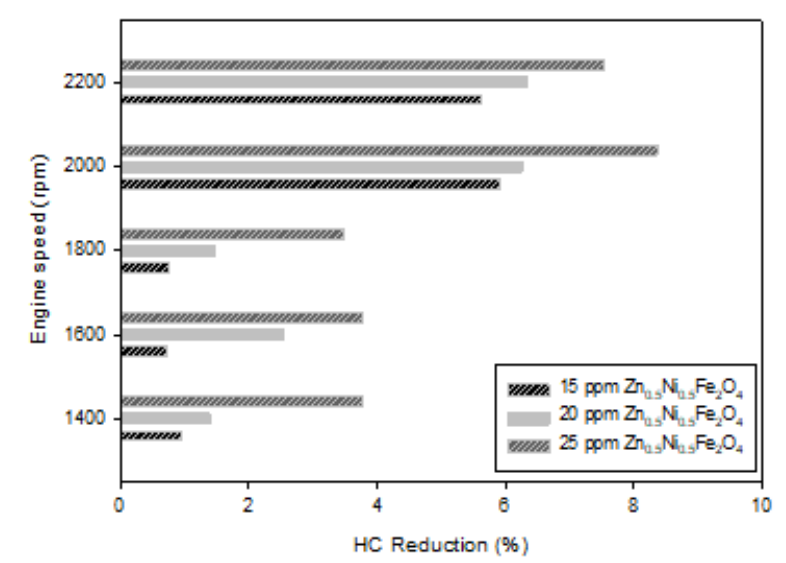

Figure 13. Percentage alteration of $\mathrm{HC}$ emissions of test fuels compared to diesel fuel

Table 8 demonstrates the changes in $\mathrm{HC}$ emissions with the addition of nanoparticle to diesel fuel at different engine speed.

\section{Conclusions}

In this experimental study the effects of $\mathrm{NiFe}_{2} \mathrm{O}_{4}$ 
Table 8. The changes in $\mathrm{HC}$ emissions with the addition of nanoparticles to diesel engine

\begin{tabular}{lllll}
\hline \multicolumn{5}{l}{$\mathrm{NiFe}_{2} \mathrm{O}_{4}$-diesel fuel blends } \\
\hline rpm & Diesel & $15 \mathrm{ppm} \mathrm{NiFe}_{2} \mathrm{O}_{4}$ & $20 \mathrm{ppm} \mathrm{NiFe} \mathrm{O}_{4}$ & $25 \mathrm{ppm} \mathrm{NiFe}_{2} \mathrm{O}_{4}$ \\
\hline 1400 & 13.64 & 13.4500 & 13.3500 & 13.2250 \\
1600 & 17.65 & 17.0580 & 17.0230 & 16.9950 \\
1800 & 19.8 & 19.5520 & 19.2560 & 19.0210 \\
2000 & 22.98 & 21.2580 & 20.8850 & 20.6650 \\
2200 & 23.95 & 23.1950 & 22.8970 & 22.6680 \\
\hline \multicolumn{5}{c}{$\mathrm{Zn}_{0.5} \mathrm{Ni}_{0.5} \mathrm{Fe}_{2} \mathrm{O}_{4}$-diesel fuel blends } \\
\hline rpm & Diesel & $15 p p m \mathrm{Zn}_{0.5} \mathrm{Ni}_{0.5} \mathrm{Fe}_{2} \mathrm{O}_{4}$ & $20 \mathrm{ppm} \mathrm{Zn}_{0.5} \mathrm{Ni}_{0.5} \mathrm{Fe}_{2} \mathrm{O}_{4}$ & $25 p p m \mathrm{Zn}_{0.5} \mathrm{Ni}_{0.5} \mathrm{Fe}_{2} \mathrm{O}_{4}$ \\
\hline 1400 & 13.64 & 13.51 & 13.450 & 13.125 \\
1600 & 17.65 & 17.52 & 17.200 & 16.985 \\
1800 & 19.8 & 19.65 & 19.510 & 19.110 \\
2000 & 22.98 & 21.62 & 21.540 & 21.056 \\
2200 & 23.95 & 22.6 & 22.430 & 22.142 \\
\hline
\end{tabular}

and $\mathrm{Zn}_{0.5} \mathrm{Ni}_{0.5} \mathrm{Fe}_{2} \mathrm{O}_{4}$ nanoparticle addition to diesel fuel on exhaust emissions of 4 Stroke- 6 cylinder turbocharged diesel engine. The results are given below:

- The NOx emission values decrease with the addition both nanoparticle additives. However, $\mathrm{NiFe}_{2} \mathrm{O}_{4}$ shows better effect in reducing NOx emissions.

- The maximum reduction on $\mathrm{CO}$ emission was achieved with $\mathrm{NiFe}_{2} \mathrm{O}_{4}$ nanoparticle addition at the dosage level of $25 \mathrm{ppm}$ to diesel fuel.

- $\mathrm{HC}$ emissions of diesel were obtained to decrease with the addition of $\mathrm{NiFe}_{2} \mathrm{O}_{4}$ and $\mathrm{Zn}_{0.5} \mathrm{Ni}_{0.5} \mathrm{Fe}_{2} \mathrm{O}_{4}$ nanoparticles. The maximum reduction was found $\mathrm{Zn}_{0.5} \mathrm{Ni}_{0.5} \mathrm{Fe}_{2} \mathrm{O}_{4}$ nanoparticle at the addition dosage level of 25 ppm as $5.4 \%$.

- Overall $\mathrm{NiFe}_{2} \mathrm{O}_{4}$ and $\mathrm{Zn}_{0.5} \mathrm{Ni}_{0.5} \mathrm{Fe}_{2} \mathrm{O}_{4}$ nanoparticle addition to diesel fuel decreases the exhaust emissions this may be due to the in promoting fuel atomization and its favorable intrinsic catalytic effect, the level of harmful pollutants (such as $\mathrm{HC}, \mathrm{CO}, \mathrm{NOx}$ ) in exhaust gases is appreciably reduced to varying degrees [21].

\section{Nomenclature}

$\begin{array}{ll}\mathrm{NiFe}_{2} \mathrm{O}_{4} & : \text { nickel iron oxide } \\ \mathrm{Zn}_{0.5} \mathrm{Ni}_{0.5} \mathrm{Fe}_{2} \mathrm{O}_{4} & : \text { nickel zinc iron oxide } \\ \mathrm{SCR} & : \text { Selective catalytic reduction } \\ \mathrm{NO}_{\mathrm{x}} & \text { : nitrogen oxide } \\ \mathrm{CO} & : \text { carbon monoxide } \\ \mathrm{HC} & : \text { hydrocarbon }\end{array}$

\section{References}

1. V.K. Kaimal, and P. Vijayabalan, "An investigation on the effects of using DEE additive in a DI diesel engine fueled with waste plastic oil", Fuel, 180, 90-96, 2016.

2. R.R. Sahoo, and A. Jain, "Experimental analysis of nanofuel additives with magnetic fuel conditioning for diesel engine performance and emissions", Fuel, 236, 365-372, 2019.

3. S. Karthikeyan, T.P. Dharma, A. Prathima, "Environment effect of La2O3 nanoadditives on microalgae-biodiesel fueled CRDI engine with conventional diesel", Energy Sources, Part A: Recovery, Utilization, and Environmental Effects, 40(2), 179-185, 2018.

4. A.H. Zhang, C.S. Cheung, T.L. Chan, and C.D. Yao, "Experimental investigation of regulated and unregulated emissions from a diesel engine fueled with Euro V diesel fuel and fumigation methanol", Atmospheric Environment, 44, 1054-1061, 2010.

5. F. Aksoy, A. Uyumaz, F. Boz, and E. Y1lmaz, "Experimental Investigation of Neutralized Waste Cooking Oil Biodiesel/Diesel Mixture and Diesel Fuel in a Diesel Engine at Different Engine Loads", International Journal of Automotive Science and Technology, 1(1), pp. 7-15, 2017.

6. D. Kannan, and W. Christraj, "Emission analysis of Azolla methyl ester with $\mathrm{Bi}_{2} \mathrm{O}_{3}$ nano additives for IC engine", Energy Sources, Part A: Recovery, Utilization, and Envi-ronmental Effects, 40(10), 1183-1189, 2018.

7. S.S. Hoseini, G. Najafi, B. Ghobadian, R. Mamat, M.T. Ebadi, and T. Yusaf, "Novel environmentally friendly fuel: The effects of nanographene oxide additives on the performance and emission characteristics of diesel engines fuelled with Ailanthus altissima biodiesel", Renewable Energy, 125, 283-294, 2018. 
8. Ş. Yıldızhan, and A. Yaşar, "Performance and Emission Characteristics of Diesel Engine Operating on Biodiesel and Biodiesel Blended with Methanol and Propanol", International Journal of Scientific and Technological Research, 1(1), 270-278, 2015.

9. Q. $\mathrm{Wu}, \mathrm{X} . \mathrm{Xie}, \mathrm{Y}$. Wang, and $\mathrm{T}$. Roskilly, "Effect of carbon coated aluminum nanoparticles as additive to biodiesel diesel blends on performance and emission characteristics of diesel engine", Applied Energy, 221, 597-604, 2018.

10. B. Sungur, B. Topaloglu, and H. Ozcan, "Effects of nanoparticle additives to diesel on the combustion performance and emissions of a flame tube boiler", Energy, 113, 44-51, 2016.

11. P. Karthikeyan, and G. Viswanath, "Effect of titanium oxide nanoparticles in tamanu biodiesel operated in a two-cylinder diesel engine", Materials Today: Proceedings, 22, 776-780, 2020.

12. P.M. Rastogi, A. Sharma, and N. Kumar, "Effect of $\mathrm{CuO}$ nanoparticles concentration on the performance and emission characteristics of the diesel engine running on jojoba (Simmondsia Chinensis) biodiesel", Fuel, 286, 119358, 2021.

13. C. Srinidhi, A. Madhusudhan, and S.V. Channapattana, "Effect of $\mathrm{NiO}$ nanoparticles on performance and emission characteristics at various injection timings using biodiesel-diesel blends", Fuel, 235, 185-193, 2019.

14. T. Özgür, M. Özcanli, and K. Aydin, "Investigation of Nanoparticle Additives to Biodiesel for Improvement of the Performance and Exhaust Emissions in a Compression Ignition Engine", International Journal of Green Energy, 12, 51-56, 2015.

15. M. Mehregan, and M. Moghiman, "Effects of nano-additives on pollutants emission and engine performance in a urea-SCR equipped diesel engine fueled with blendedbiodiesel", Fuel, 222, 402-406, 2018.

16. J.S. Kumar, B.R.R. Bapu, and R. Gugan, "Emission examination on nanoparticle blended diesel in constant speed diesel engine", Petroleum Science and Technology, 38(2), 98105, 2020.

17. T. Özgür. E.Tosun, C. Özgür, G. Tüccar, and $\mathrm{K}$. Aydin, "Effect of $\mathrm{MgO}$ nanoparticule additives on performance and exhaust emissions of diesel fuelled compression ignition engine", MATTER: International Journal of Science and Technology, 3(3), 72-85, 2017.

18. T. Ozgur, G. Tuccar, E. Uludamar, A.C. Yilmaz, C. Güngör, M. Ozcanli, H. Serin, and K. Aydın, "Effect of nanoparticule additives on NOx emissions of diesel fueled compression ignition", Int. J. Global Warming, 7(4), 487498, 2015.

19. M.A. Lenin, M.R. Swaminathan, and G. Kumaresan, "Performance and emission characteristics of a DI diesel engine with a nanofuel additive", Fuel, 109, 362-365, 2013.

20. J.S. Basha, and R.B. Anand, "An Experimental Study in a CI Engine Using Nanoadditive Blended Water-Diesel Emulsion Fuel", International Journal of Green Energy, 8, 332-348, 2011.

21. D. Mei, X. Li, Q. Wu, and P. Sun, "Role of cerium oxide nanoparticles as diesel additives in combustion efficiency Improvements and emission reduction", Journal of Energy Engineering, 142 (4), 2016. 